\title{
Do Unions Promote Gender Equality?
}

\author{
LILACH LURIE*
}

\begin{abstract}
"Many of the traditional regulations of the employment relationship no longer correspond to the real social and economic situation or to the labour market."
\end{abstract}

\author{
[Marco Biagi, Italy, in Private EMPLOYMeNT AGENCIES 267, 267 (Roger \\ Blanpain ed., 1999)]
}

Do workers' unions promote gender equality? The scholarship in the past thirty years has increasingly questioned the ability of unions to give voice to the needs of all workers, including foreign workers, workers with disabilities, elderly workers, gay and lesbian workers, and women. This article shows that unions promote a patriarchal division of labor in society through an empirical study of most of the sectorial collective agreements with employers in Israel. The fathers' role in these collective agreements is to support their family; the mothers' role is to raise the children. Thus several collective agreements provide mothers with flexible working hours and reimbursements for daycare centers, while not providing these rights to working fathers. Significant collective agreements grant working fathers, but not working mothers, with a special "family supplement" that is added to their monthly wages, increasing the gender wage-gap.

\section{INTRODUCTION}

Almost thirty years have passed since Richard Freeman and James Medoff first asked "[w]hat do unions do?"1 In their highly influential book, Freeman and Medoff challenged the traditional view that unions only create monopolies that

\footnotetext{
Copyright (C) 2014 by Lilach Lurie.

* Tel-Aviv University, Department of Labor Studies in the Faculty of Social Sciences. For helpful comments and discussions I thank: Kevin Banks, Yael Braudo-Bahat, Roger Blainpain, Hajel Conley, Guy Davidov, Ron Dol, Matthew Finkin, Magnus Granberg, Frank Hendrickx, Tammy Katsabian, Guy Mundlak, Alan Neal, Jeffrey Sack, Hila Shamir, Mia Rönnmar, Revital Turner and Steven Willborn. This paper was selected as the winner of the 2014 Marco Biagi Award. It was presented at the International Association of Labor Law Journals Annual Meeting (Dublin 2014); the International European Sociological Association Conference (Turin 2013); the Hebrew University Employment Law Workshop (Jerusalem 2013) the Equal Pay Forum (Tel-Aviv 2013) and the Faculty Seminar at Sha'arei Mishpat College (Hod-Hasaron 2013). I thank all participants for helpful comments. I would also like to thank the editorial stuff of the Duke Journal of Gender Law and Policy for their editorial and substantive comments. The Law Faculty at Bar-Ilan University provided generous funding for the research. This paper is part of a larger project regarding unions' ability to represent groups of workers.
}

1. Richard B. FREEMAN \& JAMES L. MEDOFF, WHAT DO UNIONS DO? (1984). 
lead to exaggerated wages and inefficiencies. They claimed instead that unions have two faces: "monopoly" and "voice." Unions play an important role in "voicing" workers' needs and desires to the management. Freeman and Medoff followed Albert O. Hirschman's view in "Exit, Voice, and Loyalty," emphasizing the importance of "voice" in maintaining stability and preventing employment turnover. ${ }^{2}$ While an individual employee might fear altering his employer to his needs, unions have the ability to voice workers' collective needs. ${ }^{3}$

Following Freeman and Medoff, many researchers accepted unions' role as voicing workers' needs. Yet researchers also raised questions: Whose voice do unions represent? Is it the voice of all the workers or only some of them? Groups such as women, foreign workers, workers with disabilities, elderly workers, gay and lesbian workers-are their voices heard? Do unions promote equality and diversity?

The present research contributes to the current debate by looking at the results of collective agreements and negotiations in Israel from the perspective of gender. This paper is based on an empirical study of most of Israel's sectorial collective agreements in the private and public sectors. This paper shows that collective agreements (and unions) do, in fact, promote a patriarchal division of labor. Several collective agreements provide mothers with flexible working hours and reimbursements for day-care centers. Working fathers are generally not entitled to these rights. Instead, their role is to financially support the family. Therefore working fathers-but not working mothers-are entitled to special "family supplement[s]" that are added to their monthly wages. The result of this empirical research reaffirms literature claiming that unions tend to represent the 'median' worker and under-represent 'outsiders' and workers in precarious fields.

In the past few decades, feminist scholars took part in a debate regarding several questions: What is considered a "women's interest"? What is considered "gender equality"? What are the best ways to promote gender equality? ${ }^{4}$ While feminist scholars from the "first wave of feminism" who struggled for "formal gender equality" emphasized the similarities between men and women, as well as those between one woman and another, feminist scholars from the "second wave" emphasized the differences. Furthermore, while "first wave" feminists struggled for women's right to vote and women's right for equal pay, "second wave" feminists struggled for "maternity leave" and "affirmative action." 5 In her influential book, In a Different Voice, Carol Gilligan, a "second wave" feminist,

2. AlBERT O. HiRSCHMAN, EXIT, VOICE, AND LOYALTY: RESPONSES TO DECLINE IN FIRMS, ORGANIZATIONS, AND STATES (1970).

3. FREEMAN \& MEDOFF, supra note 1.

4. Cf. Dorothy Sue Cobble, Gender Equality and Labor Movements: Toward a Global Perspective, 57, 41-48 (2012), http://www.solidaritycenter.org/Files/Rutgers\%20-

\%20Gender\%20Equality\%20and\%20Labor\%20Movements.pdf (reviewing research on gender equality and labor movements to highlight best practices); Catherine Hakim, Lifestyle preferences as determinants of women's differentiated labour market careers, 29 WORK \& OCCUPATIONS 824 (2002) (discussing a 1999 national survey in Britain that confirms that women's lifestyle preferences no longer determine occupational choice); Kathleen Kelly Janus, Finding Common Feminist Ground: The Role of the Next Generation in Shaping Feminist Legal Theory, 20 DuKE J. GENDER L. \& POL'Y 255 (2013).

5. Cobble, supra note 4; Janus, supra note 4. 
wrote about the genuine differences between men and women. ${ }^{6}$ Women, as opposed to men, are more subject to dilemmas regarding care. ${ }^{7}$ Following Gilligan, cultural feminists claimed that women should be compensated for their familial care responsibilities. ${ }^{8}$ Moreover, second and third wave feminists called for "substantive equality" or "gender mainstreaming" as opposed to the "first wave" call for equal opportunities. ${ }^{9}$ Several feminist scholars emphasized the diverse interests between women themselves. ${ }^{10}$ Every type of feminism described broadly above leads to a different understanding of "gender equality" and the ways to achieve it. Nonetheless, these important differences between the different types of feminism fade for the purposes of this article. The collective agreements examined herein infringe on gender equality however one may define it: formally, substantively, or otherwise.

\section{METHODOLOGY}

The empirical research consisted of a study of all collective agreement provisions that grant rights based on gender (only to men or only to women). The collective agreements examined are listed below. I also included in the research provisions granting rights based on parenthood (only to fathers or only to mothers).

More specifically, the research focused on provisions granting three main rights on the basis of gender: first, a right for a family supplement; second, a right to work reduced working hours; and third, a right to a day-care subsidy. The first step was to mark these provisions. The second step was to ascertain whether these provisions apply only to female workers, only to male workers, or to all employees.

The research includes almost all Israeli sectorial collective agreements: 56 agreements in total. 18 of these were public sector agreements ${ }^{11}$ and 38 were pri-

6. Carol Gilligan, In A DifFerent Voice (1982).

7. Id. at 12 .

8. Cf. Rebecca Ray, Janet C. Gornik \& John Schmitt, Who Cares? Assessing Generosity and Gender Equality in Parental Leave Policy Designs in 21 Countries, 20 J. EUR. SOC. POL'Y 196, 196-198 (2010); Majella Kilkey \& Jonathan Bradshaw, Lone Mothers, Economic Well-Being, and Policies, in GENDER AND WELFARE STATE REGIMES 147 (Diane Sainsbury ed., 1999).

9. Cobble, supra note 4 .

10. Catherine Hakim, for instance, claimed that women could be divided in to three groups according to their own preferences: Home-centered women; work-centered women and women who prefer to combine employment and family work without giving a fixed priority to either. Each group of women might prefer to promote "gender equality" in a different way. Hakim, supra note 4, at 43435. Bell Hooks maintained that mainstream feminism's reliance on white, middle-class, and professional spokeswomen obscured the involvement, leadership, and centrality of women of color and poor women in the movement for women's liberation. See BELL HOOKS, FEMINIST THEORY: FROM MARGIN TO CENTER 1-15 (2000). Feminist scholars, belonging to the "third wave of feminism" use personal storytelling to help deconstruct the myth that being a woman is a singular experience. See Janus, supra note 4; Rory Dicker \& Alison Piepmeier, Introduction to CATCHING A WAVE: RECLAIMING FEMINISM FOR THE 21ST CENTURY, 3, 5 (Rory Dicker \& Alison Piepmeier eds., 2003).

11. The research examined the agreements that apply to: technical, administrative, social scientists, engineers, doctors, veterinarians, pharmacists, psychologists, social workers, lawyers and prose- 
vate sector agreements, ${ }^{12}$ allowing a comparison between the two sectors. ${ }^{13}$ The research also includes 38 extension orders of the Israeli Minister of the Economy, which extend collective agreements to apply to all workers in the sector or in the country. ${ }^{14}$ The research additionally includes Israel's civil service regulation (Takshir) which is partly integrated in the collective agreements of the public sector. 15 Finally the research also includes all the collective agreements applicable to Teva Pharmaceutical Industries (199 agreements) and El-Al Airlines (571 agreements). ${ }^{16}$ Teva and El-Al were chosen as case studies of two corporations (in contrast to sectors) regulated by collective agreements.

This research focuses on collective agreements and not on legislation, caselaw, or "law in action", in contrast to most employment law research, which focuses on legislation and court rulings and not on collective agreements. ${ }^{17}$ Social science researchers focus on "law in action" and on the actual existence of pay gaps or discrimination in society. This is not surprising. First, collective agreements are not easy to study because they frequently change, and, in many cases, old versions are not combined, nor are they replaced by new updated versions. For example, hundreds of outdated Teva agreements were reviewed due to the lack of one updated version. Second, collective agreements-as well as union membership-are in decline, and their studies are archaic. ${ }^{18}$ Nevertheless, unions are still central players in labor market regulation. ${ }^{19}$ Collective agreements con-

cutors, biochemists, microbiologists and employees laboratories, engineers and technicians, $\mathrm{X}$-ray technicians, occupational therapists, nurses, teachers and local authority employees, and academic staff. All collective agreements were published in COLLECTIVE AGREEMENTS, VOL. 1-5 (Moshe Pasternak ed., 2013) [hereinafter Collective Agreements].

12. The research examined the agreements in the following sectors: security and protection, cleaning and maintenance, gas stations, hotel industry, plastics, textile and clothing, construction and public works, tree industry, tiles, cinema, laundries, rubber industry, leather industry, in tanning, print, cardboard, garages, metal industry, electrical and electronics, ceramics, glass, baking, juice, oils, chocolate, coffee, flour, agriculture, cigarettes, pharmaceutical industry, the diamond industry, human resource companies, import industry, exports and trade, retail trade sectors, the transport sector, mechanical engineering equipment operators, artists, travel guides, hairdresser's and remodelling contractors. All collective agreements were published in Collective Agreements, supra note 11.

13. The 18 collective agreements from the public sector apply to more workers than the 38 collective agreements in the private sector.

14. All extension orders were published in Collective Agreements, supra note 11.

15. The Takshir therefore served as a way to verify the legal status at the public sector, where there was no combined, updated version of the collective agreements.

16. These collective agreements were published on the Israeli Ministry of Industry, Trade and Labour website, available at http://apps.moital.gov.il/Agreements/Search.aspx.

17. In a search of U.S. \& Canadian law review article titles in Lexis-Nexis conducted on September 9, 2012, only six articles contained the term "collective agreements" in their title. In comparison, the term 'employment law' appears in 1,132 article titles.

18. On the decline in union density see Press Release, International Labour Organization, ILO highlights global challenge to trade unions (Nov. 4, 1997), http://www.ilo.org/global/about-theilo/press-and-media-centre/news/WCMS_008032/lang--en/index.htm\#N_1> (discussing decline in global trade-union membership); David G. Blanchflower \& Richard B. Freeman, Unionism in the United States and other advanced OECD countries, 31 INDUS. REL. 56, 57-60 (1992) (discussing major changes in the world that placed union movements in developed countries under stress).

19. See International Labour Organization, supra note 18 ("[T]he drop in union numbers has not 
tinue to regulate the working conditions of many workers throughout the world. Moreover, it seems that they will not disappear anytime soon. In the United States, for example, there are approximately 180,000 collective agreements, with 60,000 of them negotiated each year. ${ }^{20}$ Therefore, the study of collective agreements has strong policy implications.

\section{UNION REPRESENTATION THEORY}

Researchers disagree on the question of whether unions promote equality in general and gender equality in particular. Several researchers have shown that unions tend to promote wage equality (at least in corporatist countries). ${ }^{21}$ Gillian Whitehouse and Jennifer Curtin, for example, argue that the existence of centralized wage bargaining has a considerable impact on reducing the gender-wage differential. ${ }^{22}$ Others point to unions' ability to promote policies that are beneficial to workers and their families, not only in corporatist countries but also in liberal regimes such as the United States. ${ }^{23}$

Nevertheless, union representation is inherently problematic. Robert Michels, for instance, has argued that union leaders acquire and retain power over the political process, which they then use against the interests of the membership. Leadership brings importance, expertise, and different lifestyles that the leader seeks to protect. ${ }^{24}$ To give another example, Richard Hyman used a Marxist analysis of industrial relations to claim that officials were more likely to suppress irregular and distributive activities than to challenge managerial control. ${ }^{25}$

One of the problems of union representation is their tendency to advocate for the median worker. ${ }^{26}$ As unions are political institutions with contract ratification and leadership selection achieved through majority voting, this model implies that unions will negotiate compensation packages that reflect the preferences of the median worker. They do not reflect the preferences of the marginal worker. ${ }^{27}$ The commonly held opinion is that unions tend to neglect workers in

translated into a corresponding drop in influence. In most countries, trade unions have managed to consolidate their strength in core sectors, enlist constituents in emerging sectors and develop new collective bargaining strategies, often on a global scale."). Regarding Israel, see GUY MUNDLAK,

FADING CORPORATISM: ISRAEL'S LABOR LAW AND INDUSTRIAL RELATIONS IN TRANSITION (2007).

20. Jillian Crocker \& Dan Clawson, Buying Time: Gendered Patterns in Unions Contracts, 59 SoC. PROBS. 459, 461 (2012); GARY CHAISON, UNIONS IN AMERICA 107-08 (2005).

21. For a literature review on corporatism and equality, see MUNDLAK, supra note 19, at 26-30.

22. Gillian Whitehouse, Legislation and Labour Market Gender Inequality: An Analysis of OECD Countries, 6 WORK, EMP. \& SOC'Y 65, 79 (1992); JENNIFER CURTIN, WOMEN AND TRADE UNIONS: A COMPARATIVE PERSPECTIVE 149 (1999); see also Francine D. Blau \& Lawrence M. Kahn, The Gender Earnings Gap: Some International Evidence, in DIFFERENCES AND CHANGES IN WAGE STRUCTURES 105 (Richard B. Freeman \& Lawrence F. Katz eds., 1995).

23. Crocker \& Clawson, supra note 20, at 462.

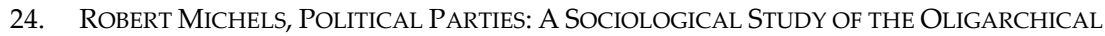
TENDENCIES OF MODERn DEMOCRACY 276-78 (Eden \& Cedar Paul trans., 1959).

25. RICHARD HYMAN, INDUSTRIAL RELATIONS: A MARXIST INTRODUCTION (1975).

26. Bruce E. Kaufman, Models of Union Wage Determination: What Have We Learned Since Dunlop and Ross?, 41 INDUS. REL. 110, 139 (2002).

27. John W. Budd, The Effect of Unions on Employee Benefits and Non-Wage Compensation: Monopo- 
the periphery and the lower echelons of the market. In a previous research study, I showed how unions tend to under-represent the interests of elderly workers. ${ }^{28}$ Several researchers have shown that unions similarly neglect the interests of foreign workers. ${ }^{29}$

Women in Israel are not a minority group in terms of the total proportion of the general population. In fact, women are about half of Israel's population and more than half of Israel's union members. ${ }^{30}$ The rate of women out of the total number of unionized and non-unionized workers is similar. The median union member could be a female just as he could be male. In other words, unions should theoretically represent women's interests just as they represent men's interests. Indeed, as noted above, several researchers point to unions' ability to promote policies which are beneficial to workers and their families. ${ }^{31}$

Nevertheless, unions tend to systematically under-represent women's interests and to promote discriminatory policies.32 There are a few explanations for this contradiction. First, although half of the unionized workers are women, most union representatives are men. Gill Kirton pointed out that women in the UK are under-represented in all levels of union decision-making structures, from the local level of workplace representatives to paid officials and executive bodies. ${ }^{33}$ This gap between the high rates of unionized women to the low rates of women among union representatives creates a "democratic deficit." 34 As Linda Dickens explains, the absence of women from the democratic process had negative results on the outcomes of the bargaining process. As a consequence, "women's issues" are inadequately addressed. ${ }^{35}$

Why are women absent from the decision-making structure of unions? Elizabeth Lawrence has succinctly answered this question by pointing out that many women have double workloads, combining paid work in employment with un-

ly, Power, Collective Voice and Facilitation, in What Do UnIOns Do? A TWENTY YeAR PersPeCtive 160, 162-64 (James T. Bennett \& Bruce E. Kaufman eds., 2007); Ton Wilthagen \& Ralf Rogowski, The Legal Regulation of Transitional Labor Market, in THE DYNAMICS OF FULL EMPLOYMENT: SOCIAL INTEGRATION THROUGH TRANSITIONAL LABOUR MARKETS 233, 244-45 (Gunther Schmid \& Bernard Gazier eds., 2002); Alain Supiot, The transformation of work and the future of labor law in Europe: a multidisciplinary

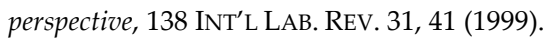

28. Lilach Lurie, Can Unions Promote Employability? Senior Workers in Israel's Collective Agreements, 42 INDUS. L. J. 249 (2013).

29. Einat Albin, Union Responsibility to Migrant Workers: A Global Justice Approach, 34 OXFORD J. LEGAL STUD. 133 (2013).

30. Yinon Cohen et al., Unpacking Union Density: Union Membership and Coverage in the Transformation of the Israeli IR System, 42 INDUS. REL. 692, 704 (2003).

31. Crocker \& Clawson, supra note 20.

32. ANNE MCBRIDE, GENDER DEMOCRACY IN TRADE UNIONS 16-17 (2001); Cynthia Cockburn, Strategies for Gender Democracy: Strengthening the Representation of Trade Union Women in the European Social Dialogue, 3 EUR. J. WOMEN'S STUD. 7, 7 (1996).

33. GILl KirTON, THE MAKING OF WOMEN TRADE UNIONISTS 12-15 (2006). On union representation in the United States, see Michelle Kaminski \& Elaine K. Yakura, Women's Union Leadership: Closing the Gender Gap, 11 J. LAB. \& SOC'Y 459 (2008).

34. KIRTON, supra note 33, at 22-3; Cockburn, supra note 32, at 18.

35. Linda Dickens, Gender, Race and Employment Equality in Britain: Inadequate Strategies and the Role of Industrial Relations Actors, 28 INDUS. REL. J. 282, 283 (1997). 
paid work at home. This double role makes it difficult for women to take a third set of tasks and responsibilities as a union office-holder. Women who find the time to serve as union office-holders are often childless or single. ${ }^{36}$ These women do not always represent the interests of working mothers.

These problems are not easily solved. Even unions that attempt to close the representation gap find results difficult to achieve. For instance, Anne McBride shows that even unions that adopted "gender democracy" strategies (i.e. reservation of seats in proportion to the number of women in the constituency) such as the British UNISON have not succeeded in promoting the empowerment of women as a social group. ${ }^{37}$ As McBride explains, "newly active [women] are less likely to speak and as a result the experienced [men] become the shapers." 38 McBride emphasizes the importance of empowering groups of women, not simply individual women. ${ }^{39}$

The second reason for unions' under-representation of women is because women tend to participate in precarious atypical work. ${ }^{40}$ Unions tend to represent the interests of the "standard" full-time worker who works for a single employer. Unions do not always have the legal capacity to represent "outsiders" such as contractors and agency workers. Even where "legal capacity" is not an issue, unions tend to prefer the standard worker. ${ }^{41}$ Women are disproportionately represented in non-standard atypical work, which may include part-time work, temporary agency work, flex-work, self-employed homecare work, and contractor work. ${ }^{42}$ All of these forms of work tend to be under-represented by unions.

The third reason for unions' under-representation of women is that unions' representatives have suffered, at least historically, from stereotypes against women. According to these stereotypes, men should work outside the house while women should concentrate on housework. A female's work should only be viewed as a small supplement to the male breadwinner's work. Furthermore, male union representatives suffer from patriarchal stereotypes. Women representatives suffer from them as well..$^{43}$ An example of these stereotypes could be found in unions' struggle in the United States., United Kingdom, Spain, and Isra-

36. ELIZABETH LAWRENCE, GENDER AND TRADE UNIONS 20-21, 87-90, 118 (1994).

37. MCBRIDE, supra note 32 , at 1-8.

38. Id. at 167 .

39. Id. at $179-81$.

40. Sandra Fredman, Women at Work: The Broken Promise of Flexicurity, 33 INDUS. L. J. 299, 301-4

(2004).

41. Supiot, supra note 27 , at 41 .

42. Definition of "atypical work," Work, EUROFOUND, http://www.eurofound.europa.eu/areas/industrialrelations/dictionary/definitions/atypicalwork.htm (last visited Oct. 30, 2014).

43. Dafna N. Izraeli \& Ada Poraz, Women and Men as Shop Stewards in Israeli Industry: Research Report (Tel-Aviv U., Inst.e for Soc. \& Lab. Res., 1980). Izraeli and Poraz show that women union officers believe that they are less influential than men. Izraeli and Poraz also show that as the proportion of women increases in the specific workplace and as the women were elected to be the chairperson they behave in a less stereotypical fashion. $I d$. at 16-17. 
el for family wage. ${ }^{44}$ The idea of family wage is one of social justice: A worker should be paid not according to his or her production, but according to his or her needs. A married worker with five children has more economic needs than a single mother. This sentiment is shared by employers as well. For example, Henry Ford paid his famous "five dollars a day" only to decently married men. Mothers earned a great deal less. ${ }^{45}$

In Israel, Histadrut-the country's major employment union-promoted "family wage" from its very first days. Local professional unions (which were all part of Histadrut Federation) promoted a "family supplement" to which only married men were entitled. During the 1930s and the 1940s, the "family supplement" constituted a large part of a married man's wage, especially when the man had several children.46 Bat-Sheva Margalit-Stern shows that, between 1920 and 1939 , there was a large wage-gap between male and female workers performing the exact same job. For example, in 1930, a man's weekly wage in the needle industry was twice that of a female counterpart. ${ }^{47}$ Margalit-Stern also shows that unions in the timber industry explicitly agreed that a decent pay for a woman should be half that of a man's. ${ }^{48}$

The fourth cause for gender discrimination is what is called "statistical discrimination." 49 Statistically, the average woman will have children. Additionally, for social and cultural reasons, in order to raise these children, the average woman will take more time out from the workforce than would the average man. ${ }^{50}$ Based on these statistics, unions assume that in contrast to men, women have other options besides working in the labor market-they can work in their house instead. Therefore, unions tend to prefer men's interests over a women's when deciding who will be dismissed, or who should receive supplements to their wages. ${ }^{51}$

\section{BACKGROUND ON ISRAEL}

\section{A. Israel's Welfare Regime}

Using Gøsta Esping-Anderson's distinctions, one may easily describe Israel

44. On family wage in the U.S., see Dorothy Sue Cobble, When Feminism Had Class, in WHAT'S ClASS GOT TO DO WiTH IT? AMERICAN SOCIETY IN THE TWENTY-FIRST CENTURY 23, 31-32 (Michael Zweig ed., 2004).

45. RAY BATCHElor, HENRY FORD, MASS PRODUCTION, MODERNISM, AND DESIGN 49-50 (1994); John R. Lee, The So-Called Profit Sharing System in the Ford Plant, 65 ANNALS AM. ACAD. POL. \& SOC. SCI. 297, 302 (1916).

46. ZEV KARMY, TRADE UNIONS IN ISRAEL 180-86 (1959).

47. BAT-SHEVA MARGALIT STERN, REDEMPTION IN BONDAGE: THE WOMEN WORKERS' MOVEMENT IN ERETZ ISRAEL 1920-1939, at 208-11 (2006).

48. Id. at 320 .

49. Richard A. Posner, An Economic Analysis of Sex Discrimination Laws, 56 U. CHI. L. REV. 1311, 1320 (1989).

50. Id. at $1315-17$.

51. CLAUS OFFE, DISORGANIZED CAPITALISM: CONTEMPORARY TRANSFORMATIONS OF WORK AND POLITICS 41-42, 159 (1985). 
as a corporatist regime with social democratic elements. ${ }^{52}$ In past decades, Histadrut lost control over its healthcare and pension plans, but it is still part of a tripillar roundtable that decides employment and economic policies in the country. $5356 \%$ of Israeli workers are covered by collective agreements, but only $34 \%$ of Israeli workers are unionized (compared to $80 \%$ in the 1980s). ${ }^{54}$ This gap between union membership and collective agreements' coverage is a result of Israel's corporatist legislation. ${ }^{55}$ The Collective Agreements Law declared that collective agreements apply to all employees included in the agreement, no matter their membership status. ${ }^{56}$ Moreover, due to the ministry's power to extend a collective agreement, an agreement can also apply to employers who were not parties to the collective agreements and to their employees. ${ }^{57}$

\section{B. Women in Unions}

Unlike unions in many other countries, Histadrut never excluded women from union membership. ${ }^{58}$ Since the first days of Histadrut, female members tried to promote women workers' interests through three separate bodies within Histadrut: the Women's Workers Movement, the Organization of Working Mothers, and the Department for Salaried Women.59 The Women's Workers Movement and the Organization of Working Mothers later merged and renamed themselves $\mathrm{Na}^{\prime}$ amat. $\mathrm{Na}^{\prime}$ amat was concerned with women's interests as a whole,

52. Esping-Anderson acknowledges in his book that each country might have a few elements from several welfare regimes. See GøSTA ESPING-ANDERSON, THE THREE WORLDS OF WELFARE CAPITALISM 26-29 (1990). Stier, Lewin-Epstein, and Braun describe Israel's welfare regime as a conservative-corporatist welfare state with a high level of support to mothers' employment. Haya Stier et al., Welfare Regimes, Family-Supportive Policies, and Women's Employment along the Life-Course, 106 AM. J. SOC. 1731, 1740 (2001). Mundlak claims that the industrial relations and labour law in Israel changed from a European style of corporatism to a model of pluralism. MUNDLAK, supra note 19, at 35. But see his later work Guy Mundlak, Addressing the Legitimacy Gap in the Israeli Corporatist Revival, 47 BRIT. J. INDUS. REL. 765 (2009) (discussing several episodes of nationwide collective agreements and social pacts in recent years). In the past few decades Israel has adopted more and more characteristics of a "liberal welfare regime" including a privatization policy. Daphne Barak-Erez, The Public Law of Privatization: Models, Norms and Challenges, 30 TEL-AvIV U. L. REV. 461, 500 (2008); EYAL PELEG,

PRiVAtization as Pollicization: PRIVATIZEd Bodies IN PUblic LAW (2005).

53. MUNDLAK, supra note 19, at 121-24.

54. Haberfeld et al., Trade Union Density in Israel 2000-2006: Years of Stagnation, 12 LAB., SOC'Y. \& LAW 2-3(2010); Cohen et al., supra note 30, at 692-712; MUNDLAK, supra note 19, at 43-44.

55. MUNDLAK, supra note 19 , at 51.

56. Collective Agreements Law 5717-1957, §§ 15-16 (1957) (Isr.), available at http://www.moital.gov.il/NR/exeres/9034396F-AC64-4C44-9466-25104B45FBB1.htm.

57. Id. at $\S 30$. In almost all EU member states, mechanisms exist to make collective agreements legally binding for all employees and employers in a certain sector or in the entire country. On collective bargaining agreements in the EU see Peter Kerckhofs, Extension of Collective Bargaining Agreements in the EU, EUROFOUND (2011), available at www.eurofound.europa.eu/pubdocs/2011/54/en/1/EF1154EN.pdf.

58. CURTIN, supra note 22, at 98.

59. Id. at 99. 
including workers and non-workers. ${ }^{60}$ For example, Na'amat established a network of 280 day care centers for over 20,000 infants and toddlers, which are still in operation today. $\mathrm{Na}^{\prime}$ amat also provides legal counseling for individual and groups of women. ${ }^{61}$ The Department for Salaried Women was intended to attend to women's interests in collective agreements and to promote equal pay and reduced working hours for working parents. ${ }^{62}$ Currently this department emphasizes the training of potential female union representatives. However, neither the Department for Salaried Women nor Na'amat is a powerful section within Histadrut. 63

Histadrut's constitution contains representation quotas for women in a few of its leading bodies: ${ }^{64}$ Histadrut's House of Representatives has 171 members and Histadrut's Congress has 2001 members. ${ }^{65}$ In elections to both institutions, women should make up at least $30 \%$ of the parties' lists. ${ }^{66}$ Histadrut subjects sectorial unions to the quota system as well. ${ }^{67}$ However, the quota system does not apply to Histadrut's Leadership, which is the highest body of Histadrut. As of November 2013, there are only five members in Histadrut's Leadership, which consists of 49 members. ${ }^{68}$ Moreover, men have always occupied the highest position in Histadrut, the Secretary General. ${ }^{69}$

\section{Gender Anti-Discrimination Legislation}

Until the end of the 1980s, few Israeli laws specifically dealt with matters of gender equality in the workplace. ${ }^{70}$ Since then, Israel's parliament has enacted only a few statutes to provide gender equality in the workplace. In 1987, the Equal Retirement Age prohibited gender discrimination in the mandatory retirement age. ${ }^{71}$ In 1988, the Employment (Equal Opportunities) Law prohibited

60. Izraeli \& Poraz, supra note 43 , at $12-15$.

61. About Na'amat, NA'AMAT, http://www.naamat.org.il/aboutE.php?cat=183\&incat=0 (last visited Oct. 31, 2014).

62. Izraeli \& Poraz, supra note 43 , at $12-15$.

63. CURTIN, supra note 22; Izraeli \& Poraz, supra note 43, at 13.

64. For the history of quotas for women in Histadrut, see CURTIN, supra note 58, at 100-02; Izraeli \& Poraz, supra note 43 , at 13 .

65. Histadrut, Histadrut's Constitution Chapter 4(2)(A),(2011), available at http://www.histadrut.org.il/files/684fa1c2c20308be189cc9ded6ca7e5c.pdf .

66. Id. at Chapter $4(2)(\mathrm{B})(15)$.

67. Id. at Chapter 6.

68. Histadrut Leadership, HISTADRUT, http://www.histadrut.org.il/index.php?page_id=16 (last visited Nov. 7, 2014) [hereinafter Histadrut Leadership].

69. The History of Histadrut, HISTADRUT

(2013),http://www.histadrut.org.il/index.php?page_id=296 (last visited Oct. 31, 2014) [hereinafter Histadrut History].

70. Ruth HALPERIN-KADDARI, WOMEN IN ISRAEL: A STATE OF THEIR OWN 115 (2004). Exceptions were the Women's Equal Right Law from 1951 which demanded that "one law apply to men and women regarding every legal action." Id. at 115-16. Another exception was the Equal Pay Law from 1964. Id. at 115.

71. Id. at 116. The law was later replaced by the Retirement Age Act from 2004. 
gender-based discrimination in all stages of employment, from hiring to working conditions, promotions, and termination. ${ }^{72}$ Furthermore, the Male and Female Workers Equal Pay Law from 1996 (which replaced the 1964 Equal Pay Law) added an explicit right to equal pay for the same work. ${ }^{73}$ This law declared that men and women employed by the same employer in the same workplace are entitled to equal pay for the same work. ${ }^{74}$ The findings of this article presented below will show that several collective agreements violate this express provision, by providing different wages to men and women. Nevertheless, Israeli law is clear in prohibiting such gender-based discrimination. ${ }^{75}$ Moreover, in the Israeli legal system, whenever a conflict appears between the provisions of a statute and the provisions of a collective agreement, the provisions of the law shall prevail and override. ${ }^{76}$

In tandem with the gender equality legislation described above, Israel's law has also shifted from providing mothers' rights to providing overall parental rights. ${ }^{77}$ While the Employment of Women Law of 1954 provided a right to a paid maternity leave only for working mothers, amendments expanded the rights to working fathers as well. Today, Israeli women are entitled to 14 weeks paid maternity leave and up to a year unpaid leave. Israel's law protects new working mothers from dismissal and forbids employers from discharging the mothers during their leave (whether paid or unpaid) and for sixty days from their return to work. ${ }^{78}$ While working fathers are entitled to utilize most of these rights instead of their female partners, the law still defines mothers as the main users of these rights. A father may use the right only when the mother relinquishes it.

Not only are fathers entitled to take maternity leave, Article 4 of Israel's Employment (Equal Opportunities) Law from 1988 declares that "where ... a woman employee has any entitlement by virtue of her being a parent, such entitlement shall also be accorded to a male employee at the workplace where the aforesaid term of employment is customary."79 This law declares that a right to "a shortened working day" and "to use the services of a day care center" should be provided equally to both male and female parents (whenever provided to mothers). ${ }^{80}$ While this equal entitlement provision presents a significant move

72. Employment (Equal Opportunities) Law, 5748-1988 (1988) (Isr.). The original law from 1988 prohibited gender based discrimination and discrimination due to marital status. During the 90 s the Israeli parliament added to the law 14 categories of prohibited discrimination. $C f$. MUNDLAK, supra note 19 , at $181-182$.

73. Male and Female Workers Equal Pay Law, 5756-1996 (1996) (Isr.).

74. The Male and Female Workers Equal Pay Law 5756-1996, §2 (1996) (Isr.), available at http://www.moit.gov.il/NR/rdonlyres/8CFAB6A8-B2AA-4E42-A2DE-0CF2A1ECB012/0/14.pdf.

75. The Male and Female Equal Pay Law from 1996 was recently enforced by the courts at HCJ 1758/11 Orit Goren v. Homecentre (2012) (Isr.).

76. Collective Agreements Law 5717-1957 (1957) (Isr.), available at http://www.moital.gov.il/NR/exeres/9034396F-AC64-4C44-9466-25104B45FBB1.htm.

77. HALPERIN-KADDARI, supra note 70, at 112.

78. Employment of Women Law, 5714-1954, §§ 6-9 (1954) (Isr.), available at http://www.moital.gov.il/NR/rdonlyres/D1F1E33F-9227-49DA-8E74-BC8D523C642F/0/13.pdf.

79. Employment (Equal Opportunities) Law, 5748-1988(4) (1988) (Isr.).

80. Id. 
away from mothers' rights towards parents' rights, the transition, as noted above, is incomplete. The law still defines mothers as the main users of these rights, and the fathers may only utilize them instead of the mothers if they decline to use them.

\section{Women in Israel's Labor Market}

While Israeli law seems progressive in its approach to gender equality, women's position in the Israeli labor market is far from satisfactory. ${ }^{81}$ Fewer women work than men, and the women who do earn less than their male counterparts. For example, according to the Israeli Central Bureau of Statistics, in $2012,69 \%$ of Israeli males took part in the labor force, compared to only $58 \%$ of Israeli females. ${ }^{82}$ Both rates are below OECD average: in 2011, 79\% of men and $65 \%$ of women participated in the labor force in OECD countries. ${ }^{83}$

Israeli women (as their fellows in the OECD) ${ }^{84}$ not only work less than men, but also earn less (Table 1). One explanation for the wage gap is the gender differences in the number of working hours per week. Women work less and, therefore, earn less. But even if we compare the payment for a single hour of work, we find a wage gap between men and women. As the Israeli Central Bureau of Statistics shows, women earn less in almost all sectors except the construction sector. 85

\section{E. Israel's Civil Service Regulation (the Takshir)}

Workers in the Israeli public sector are subject to the Israeli Civil Service Regulation (the Takshir). In June 2013, Israel's Civil Service Commission revised the Takshir entitling parents (mothers and fathers) to enjoy rights to reduced working hours. ${ }^{86}$ Israel's Civil Service Commission also revised the term "moth$\mathrm{ers}^{\prime}$ job" to the term "parents' job." 87 The change of terms was not only a rhetorical gesture, but it was a real attempt to "increase equality in the distribution of roles in the family, to further help working mothers and to make it easier for state employee fathers to take their parenting rights, and spend more time with

81. Noya Rimalt, From Law to Politics: the Path to Gender Equality, 18 ISR. STUD. 5, 6-7 (2013).

82. Males Aged 15 and Over, by Labour Force Characteristics, ISRAELI CENTRAL BUREAU OF STATISTICS, http://www.cbs.gov.il/publications13/saka0613m/pdf/tab02_m.pdf (last visited Oct. 31, 2014); Females Aged 15 and over by Labour Force, IsRAELI CENTRAL BuREAU OF STATISTICS,

http://www.cbs.gov.il/publications13/saka0613m/pdf/tab03_m.pdf (last visited Oct. 31, 2014).

83. Employment: Labor force participation rate, by sex, OECD

http://stats.oecd.org/index.aspx?queryid=54751 (last visited Oct. 31, 2014).

84. Israel's wage gender gap (20.7) is a bit higher than the OECD's average wage gender gap (15). Employment: Labor force participation rate, by sex, OECD,

http://stats.oecd.org/index.aspx?queryid=54751 (last visited Oct. 31, 2014).

85. Gross Income Per Employee by Industry and Sex, ISRAELI CENTRAL BUREAU OF STATISTICS, http://www.cbs.gov.il/www/publications13/1524/pdf/t21.pdf (last visited Oct. 31, 2014).

86. Israel's Civil Service Regulation, Change of the term "mother's hours of work" to "parent's hours of work" (2013). http://csc.gov.il//DataBases/NashamPosts/Documents/tashag18.pdf.

87. Id. 
their children." The revision in the Takshir is in line with Article 4 of the Employment (Equal Opportunities) Law of 1988. According to the Takshir, all parents working in Israel's civil service are entitled to "family rights," which include reduced working hours and employer contribution for day care costs. However, this right is not automatically realized. The parent must file a form declaring that she or he wishes to realize the right, that her or his partner is working (employed or self-employed), and that her or his partner is not realizing the right herself or himself (even if the right does not exist in the partner's workplace).

\section{FINDINGS}

Most collective agreements in the private sector contain a section entitled "employment of women." Despite the promising title, this section regularly declares that "[a] female worker will be entitled to her rights in accordance to the law" and nothing more. 88 This section does not provide women with any other right beyond her legal rights as defined in Israel's extensive legislation. Moreover, the findings of this research show that Israel's collective agreements often contradict the law, providing rights that discriminate between men and women. The research points to three rights provided on the basis of gender: a right to a family supplement, a right to work reduced working hours, and a right to day care expenditures.

\section{A. Men Are Entitled to a Higher Salary than Women}

One major finding of the research is that according to most of Israel's collective agreements, married men are entitled to higher wages than married women. In $55 \%$ of all collective agreements and in $74 \%$ of the collective agreements in the private sector, a married man is entitled to a special supplement to his salary, provided that his wife is not working (Table 2). Married women whose spouses are not working are not entitled to the same benefits. For example, the collective agreement in the leather industry declares that "married employees are entitled to a 'family supplement' for non-working wives." 89 The sum of the supplement is about one Israeli Shekel $(\$ 0.30)$ a day. ${ }^{90}$ The right for a family supplement appears only in $17 \%$ of the collective agreements in the public sector. Five collective agreements in the private sector and a single collective agreement in the public sector integrated the family supplement into the salary.

Most collective agreements in the private sector provide the right only to married men whose wives are not working. Only a single collective agreement in the agriculture sector contains an egalitarian clause declaring that "the right for

88. E.g., Drivers' Collective Agreement, article 65; Collective Agreement in the Plastic Industry, article 11; Collective Agreement in the Coffee Industry, article 57, in Collective Agreements, supra note 11.

89. Collective Agreement in the Leather Industry, article 9, in Collective Agreements, supra note 11.

90. A search through the Israeli legal search engine, Nevo, shows that hundreds of plaintiffs sued for and received the family supplement from their employers. This right appears in 391 cases. 
family supplement [is given] for non-working partner (men or women)." 91 Several collective agreements extend the right to widows and to women who are married to men with disabilities. ${ }^{92}$ Some collective agreements extend the right to divorced women who are sole breadwinners. ${ }^{93}$ One collective agreement provides the right to mothers of small children under 14 who are sole breadwinners. ${ }^{94}$

\section{B. Only Mothers Are Entitled to Work Reduced Working Hours}

Israel's collective agreements contain two main arrangements of reduced working hours for parents. The first arrangement is the right of parents with young children to work reduced hours while their children are young. The second right is the right of parents to work an hour less a day in the first year following the birth of their child. Collective agreements provide both rights mainly to mothers. Fathers are entitled to the right only if their partners have died and they care for their children by themselves. Surprisingly, the collective agreements have not changed through the years and do not comply with the amended legislation or the Takshir, which entitles both parents to enjoy the right.

As to the first right, to work reduced working hours, most collective agreements in the public sector entitle parents of young children to work reduced hours while their children are young (Table 3). In fact, the only collective agreement in the public sector that does not contain such a right is the collective agreement regarding academic staff. The ages of the children differ in the collective agreements. For example, the doctors' collective agreement enables parents of two children younger than twelve or of one child (or more) younger than eight to work reduced hours. ${ }^{95}$ None of the sectorial collective agreements in the private sector contain such a right, nor do the collective agreements in Teva and ElAl.

As to the second right, several collective agreements in the public sector entitle a parent to work an hour less a day in the first year following the birth of her child (Table 4). In several collective agreements, the right is defined as a "nursing hour," although the agreements do not explicitly give this benefit to nursing mothers. This right broadens the legal right (given to every mother in Israel) to be absent from work "from the end of the maternity leave until the end of 4 months thereafter - one hour per day. . . ."96 Surprisingly, most collective agreements in the public sector do not contain this right even though it appears in the Takshir. None of the sectorial collective agreements in the private sector contain such a right.

91. Appendix B to the extension order, supra note 11.

92. E.g., the Collective Agreement in Gas Stations, article 7d; the Collective Agreement in the Chocolate Industry, article 4.3, in Collective Agreements, supra note 11.

93. Collective Agreement in the Cardboard Industry, article 10, in Collective Agreements, supra note 11 .

94. Collective Agreement in the Cleaning Industry, article 8, in Collective Agreements, supra note 11.

95. Doctors' Collective Agreement, article 5, in Collective Agreements, supra note 11.

96. Employment of Women Law, 5714-1954 § 7(c)(3) (1954) (Isr.). 


\section{Only Mothers Are Entitled to Day Care Expenditures}

All collective agreements in the public sector contain a right to a day care subsidy (Table 5). Only two collective agreements in the private sector, in the agriculture sector and hotels industry, contain such a right. The collective agreements in Teva ${ }^{97}$ and in El-Al provide the right as well. ${ }^{98}$

Most collective agreements provide the right to day care subsidies mainly to mothers. Fathers are entitled to the right only if they are widowers or divorced (Table 6). Only the collective agreement for academic staff provides an equal parental right to a day care subsidy (Table 6). As noted above, according to Israel's legislation, fathers are entitled to the right subject to a few conditions. Nevertheless, the social partners (trade unions and employers) have yet to revise most collective agreements and they do not fit the law.

The terms of eligibility to the benefit differs from one collective agreement to another. In most collective agreements, the right is provided to mothers of children under the age of five. ${ }^{99}$ The sum of the benefit differs as well. None of the collective agreements provide a day-care center for the workers' children. None of the collective agreements provide a full refund of day-care expenses. Most collective agreements in the public sector provide a benefit of between $\$ 80$ (for one child under the age of five) and $\$ 140$ (for two or more children under the age of five). ${ }^{100}$

\section{DISCUSSION}

\section{A. Unions Promote a Patriarchal Division of Labor}

The findings reinforce the assumption that unions promote a patriarchal division of labor. The collective agreements provide a right to family wage only to men and a right to reduced working hours and day care expenditures only to women. The collective agreements' subtext is clear: men should go to work and women should stay at home. The collective agreements in the public sector provide women with some kind of compensation in return for their low income. This compensation takes the form of reduced working hours and day care expenditures, and it allows mothers in the public sector to combine "work" and "care." Women in the private sector receive no compensation in return for their low wages but are expected to stay at home. While collective agreements in the

97. Collective Agreement in Teva 840755 (1984a); Collective Agreement in Teva 840883 (1984b);

Collective Agreement in Teva 850475 (1985), supra note 16.

98. Collective Agreement in El-Al 900588 (1990), supra note 16.

99. E.g., Collective Agreement in the Hotel Industry, Article 43; Collective Agreement of Social Workers, article 24c, in Collective Agreements, supra note 11.

100. In Israeli shekels, the sum is between 300 and 500 shekels. These are the "default" rates in the Israeli civil service. See Memorandum from the Head of the Wages and Labor Agreements Departments N. to Union Members (Jan. 4, 2011), available at

http://www.pionet.co.il/hahistadrut_pdf/doc20040608185450.pdf. 
public sector promote substantive gender equality, the collective agreements in the private sector do not promote formal equality or substantive equality.

The findings reinforce the literature presented in the first part of the paper, and show that although women constitute half of union members, unions do not adequately address women's interests. The collective agreements do not give women a real opportunity to decide how to balance work and family.

The first explanation for the findings is that unions do not represent women's interests due to a lack of representation. Although women are half of the population and half of the unionized workers, women are not adequately represented in unions' senior positions and committees. In fact, since the establishment of Histadrut in 1921, only men served as its chairmen.101 Today, as in the past, mostly men serve in Histadrut's management functions. Only five women serve in Histadrut leading board, compared to 44 men. ${ }^{102}$ This lack of representation stands in contrast to Histadrut's efforts through the years to promote women in its institutions.

The second explanation for the findings is simply "old" stereotypes against women. The research reveals that unions (and employers) apply discriminatory biases in the collective agreements the workers sign. They consider female workers to be workers who have another option besides work and thus deserve a lower salary. These findings reinforce the research mentioned above that show that unions seem to implement discriminatory practices against foreign workers and elderly workers. ${ }^{103}$ Prior research also shows that women representatives often apply similar practices to their male colleagues. ${ }^{104}$ Simultaneously, research shows that women apply discriminatory practices only when they are a small minority in the representative bodies and feel they must act according to their male colleagues' rules. ${ }^{105}$ In places where women are represented in high numbers, women do not feel as pressured to apply discriminatory practices. ${ }^{106}$

\section{B. The Public Sector versus the Private Sector}

The findings also point to a large difference between the public sector and the private sector. While the collective agreements in the public sector clearly promote a patriarchal division of labor (men are entitled to a "family supplement" while women are not), the collective agreements in the public sector promote a much more equal division of labor. Almost all of the collective agreements in the public sector provide working mothers with a right to work reduced hours as well as a right to receive day care expenditures. These rights enable women to take part in the labor market and to combine both working at home and out of it. These "family rights" could perhaps explain the relatively large

101. CURTIN, supra note 22, at 98.

102. Histadrut Leadership, supra note 68.

103. See Albin, supra note 29, at 150; Lurie, supra note 28, at 263.

104. Izraeli \& Poraz, supra note 43 , at $16-17$.

105. Id.

106. Id.; Drude Dahlerup, From a Small to a Large Minority: Women in Scandinavian Politics, 11 SCANDINAVIAN POL. STUD. 276, 275-298 (1988). 
rates of women working in the public sector in Israel.107

Public sector collective agreements could promote even more equality by providing rights to both parents and not only to mothers. In fact, current policy and feminist literature emphasize the importance of providing "parent rights" also to fathers. ${ }^{108}$ According to this literature, the way to reach equal participation of men and women in the labor market is through enabling men to take equal part in domestic tasks. ${ }^{109}$ Creating an equal division in domestic tasks also leads to wage equality. When men are able to equally share the domestic tasks with women, women will be able to work more hours and earn more salaries.

Although unions could promote more equality in the public sector by promoting parents' rights, public sector collective agreements still promote much more equality than private sector collective agreements. One explanation for the discrepancy could be the different characteristics of unions. However, this explanation does not seem to be comprehensive enough because in Israel, Histadrut represents most of the workers in both the public and the private sectors.

The second explanation could be that although the same union represents both sectors, the local workers' representatives in the public and private sectors promote different interests. While in the private sector the average worker could be either a woman or a man, in the public sector, most of the workers $(65 \%)$ are women. ${ }^{110}$ According to the literature, it could be expected that in "female workplaces" women's interests would be represented. However, it is hard to determine causality: are there many women because of the accommodated working conditions or are the working conditions a result of female authority in the workplace?

The third and most likely explanation is that the differences between the two sectors have nothing to do with unions. According to this explanation, these rights were not a result of collective negotiation. The employer himself decided to provide these rights to workers and to include them in the collective agreements. This explanation fits the June 2013 decision to replace "mother rights" in the public sector with "parent rights." As noted above, Israel's civil service commission decided to extend the right to work reduced working hours and the right to day care expenditures to fathers. Currently, both mothers and fathers in the public sector can enjoy these rights. Surprisingly, the unions were not involved in this reform. The reform was a sole decision of the civil service commission. If this last explanation is correct, unions in Israel are affirmatively promoting gender equality in neither sector.

107. Stier et al., supra note 3, at 1734-35; Orly Almagor-Lotan, Wage Differentials between Men and Women in the Public Sector: Findings from the report at the Finance Ministry, Presented to the Committee on the Status of Women, available at http://www.knesset.gov.il/mmm/data/pdf/m02950.pdf.

108. See Ray, Gornik \& Schmitt, supra note 8, at 199 (“The so-called 'dual-earner/dual-carer' model, with some variations, has been developed and clarified mainly by feminist welfare state scholars in Europe ... The 'earner-carer' model envisions a society in which men and women engage symmetrically in both paid work and unpaid caregiving ...") (internal citations omitted); Julia L. Ernst, Review Essay: The UN Convention on the Elimination of all Forms of Discrimination against Women: A Commentary, 13 MELB. J. INT'L L. 890, 915-17 (2012).

109. Cf. Ruth Lister, Citizenship: FeMinist PerspeCtives 130- 44 (1997).

110. Almagor-Lotan, supra note 107. 
While all three of the explanations above are possible, the final outcome is the same: collective agreements in the public sector provide better gender equality than collective agreements in the private sector. The public sector in Israel is in a constant threat of downsizing. A long series of government decisions in the past decade threatens to privatize large portions and shrink its size. Fewer workers are expected to enjoy the public sector's gender equality in the future.

\section{Illegality}

A final but extremely important finding is that most collective agreements violate the law. ${ }^{111}$ Conley shows that in the United Kingdom, unions promoted equal pay through legislation, not through collective agreements. Instead of changing the collective agreements themselves, unions asked the courts to require the employer to pay equally. Conley associates this tool with the decentralized system of collective agreements in the United Kingdom, which also contributes to similar results in the United States. ${ }^{112}$ In Israel the system of collective agreements is more centralized: there are extended sectorial collective agreements. The corporatist Israeli structure could therefore explain in some part, the unions' reluctance and even resistance to use legislation to provide equal pay. In fact, in Israel, NGOs, rather than unions, are the active agents who fight for equal pay. Nevertheless this does not explain why unions did not change collective agreements with employers to make them comply with the law. The illegality in collective agreements remains a stark anomaly and a flagrant case of gender discrimination.

\section{CONCLUSION}

Almost thirty years have passed since Freeman and Medoff wrote their influential book on what unions do. ${ }^{113}$ Twenty years later, Freeman, who believes himself "older and presumably wiser,"114 pointed to two errors in his book. The first was the "failure to take account of unionism outside the U.S." Freeman regretted the book's ignorance of more centralized and state-influenced economic systems where the tool of extension orders exists. ${ }^{115}$ The second error was the "failure to analyze public sector unionism."116 Freeman admitted that due to the drop in unions' power in the U.S. private sector, it seemed more important to research unions' role in the public sector.

111. Employment of Women Law, 5714-1954 §§ 6-9 (1954) (Isr.); Male and Female Workers Equal Pay Law, 5756-1996 (1996) (Isr.).

112. Hazel Conley, Trade unions, equal pay and the law in the UK, 35 ECON. \& INDUS. DEMOCRACY 309, 310-12 (2013).

113. FREEMAN \& MEDOFF, supra note 1.

114. Richard B. Freeman, What Do Unions Do? The 2004 M-Brane Stringtwister Edition 2((Nat'1 Bureau of Econ. Research, Working Paper No. 11410, 2005), available at http://www.law.harvard.edu/programs/lwp/2005June.pdf.

115. Id. at 7-11.

116. Id. 
The current research recognizes and seeks to correct both errors. It analyzes unions' role in Israel, a relatively corporatist centralized system, to show that they do not promote gender equality but in fact, promote a patriarchal division of labor. Are these findings unique to Israel's institutional features or do they have broader implications? In 2005, Freeman claimed that "unions have a monopoly face and a voice face. The mix between them and the impact of unions on economic and political outcomes depends on the environment in which unions operate."117 Israel is a single example dependent on its particular environment. Nevertheless, I believe that the current research might have broader implications regarding corporatist and liberal regimes, especially because the findings of the current research are consistent with other research done in liberal regimes. These consistencies are suggestive rather than conclusive, yet they pessimistically imply that unions in corporatist and liberal regimes do not promote gender equality.

This paper also contributes to our knowledge on unions in the public sector. The research reveals the great difference between collective agreements in the public sector and in the private sector, pointing to the unique "family-friendly policy" in public sector collective agreements. This finding is important because of the relative decline in union density in the private sector in many countries (the United States and Israel among them) and therefore to the greater importance of unions in the public sector. The findings give the state itself rather than the unions the credit for the above "family-friendly policy". Yet again, the shortcomings of unions in promoting gender equality are manifest.

TABLES

Table 1: Gross Income Per Employee By Gender

\begin{tabular}{|l|l|l|}
\hline & Women & Men \\
\hline $\begin{array}{l}\text { Gross Income Per Month } \\
\text { (NIS) }\end{array}$ & 6,600 & 9,976 \\
\hline $\begin{array}{l}\text { Gross Income Per Work } \\
\text { Hour (NIS) }\end{array}$ & 44 & 53 \\
\hline $\begin{array}{l}\text { Number of Working } \\
\text { Hours Per Week }\end{array}$ & 35.9 & 44.5 \\
\hline
\end{tabular}

Israeli Central Bureau of Statistics 2011a

Table 2: A Right to a Family Supplement

\begin{tabular}{|l|l|l|}
\hline & $\begin{array}{l}\text { A family supplement } \\
\text { right }\end{array}$ & $\begin{array}{l}\text { No family supplement } \\
\text { right }\end{array}$ \\
\hline All sectorial collective & $55 \%$ & $45 \%$ \\
\hline
\end{tabular}




\begin{tabular}{|l|l|l|}
\hline agreements $(\mathbf{N}=\mathbf{5 6})$ & & \\
\hline $\begin{array}{l}\text { Collective agreements in } \\
\text { the private sector } \mathbf{( N ~}= \\
\text { 38) }\end{array}$ & $74 \% *$ & $26 \%$ \\
\hline $\begin{array}{l}\text { Collective agreements in } \\
\text { the public sector } \mathbf{( N = 1 8})\end{array}$ & $17 \%^{* *}$ & $83 \%$ \\
\hline El-Al & No & Yes \\
\hline Teva & No & Yes \\
\hline
\end{tabular}

*Including five collective agreements that integrated the family supplement into the salary.

**Including one collective agreement that integrated the family supplement into the salary. In all the collective agreements in the public sector the supplement might be void.

Table 3: A Right to Reduced Working Hours in Israel's Sectorial Collective Agreements

\begin{tabular}{|l|l|l|}
\hline & $\begin{array}{l}\text { Collective agreements } \\
\text { with flexible working } \\
\text { hours }\end{array}$ & $\begin{array}{l}\text { Collective agreements } \\
\text { without flexible working } \\
\text { hours }\end{array}$ \\
\hline $\begin{array}{l}\text { All sectorial collective } \\
\text { agreements (N=56) }\end{array}$ & $30 \%$ & $70 \%$ \\
\hline $\begin{array}{l}\text { Collective agreements in } \\
\text { the public sector (N=18) }\end{array}$ & $94 \%$ & $6 \%$ \\
\hline $\begin{array}{l}\text { Collective agreements in } \\
\text { the private sector (N=38) }\end{array}$ & - & $100 \%$ \\
\hline Teva & Yes & \\
\hline El-Al & Yes & \\
\hline
\end{tabular}

Table 4: A right to a "Nursing Hour"

\begin{tabular}{|l|l|l|}
\hline & $\begin{array}{l}\text { Collective agreements } \\
\text { with 'nursing hours' }\end{array}$ & $\begin{array}{l}\text { Collective agreements } \\
\text { without 'nursing hours' }\end{array}$ \\
\hline $\begin{array}{l}\text { All sectorial collective } \\
\text { agreements (N=56) }\end{array}$ & $8 \%$ & $92 \%$ \\
\hline $\begin{array}{l}\text { Collective agreements in } \\
\text { the public sector (N=18) }\end{array}$ & $28 \%$ & $72 \% *$ \\
\hline $\begin{array}{l}\text { Collective agreements in } \\
\text { the private sector (N=38) }\end{array}$ & - & $100 \%$ \\
\hline Teva & Yes & \\
\hline El-Al & Yes & \\
\hline
\end{tabular}

*Most of the workers in the public sector are entitled to a 'nursing hour' due to the provisions of the Takshir. 
Table 5: A Right to Day Care Expenditures in Israel's Sectorial Collective Agreements

\begin{tabular}{|l|l|l|}
\hline & $\begin{array}{l}\text { Collective Agreements } \\
\text { with Day Care Expendi- } \\
\text { tures }\end{array}$ & $\begin{array}{l}\text { Collective Agreements } \\
\text { without Day Care Ex- } \\
\text { penditures }\end{array}$ \\
\hline $\begin{array}{l}\text { All sectorial collective } \\
\text { agreements (N=56) }\end{array}$ & $36 \%$ & $64 \%$ \\
\hline $\begin{array}{l}\text { Collective agreements in } \\
\text { the public sector (N=18) }\end{array}$ & $100 \%$ & 0 \\
\hline $\begin{array}{l}\text { Collective agreements in } \\
\text { the private sector } \\
\text { (N=38) }\end{array}$ & $5 \%$ & $95 \%$ \\
\hline Teva & Yes & \\
\hline El-Al & Yes \\
\hline
\end{tabular}

Table 6: A Right to Day Care Expenditures: For Whom?

\begin{tabular}{|l|l|l|l|l|}
\hline & $\begin{array}{l}\text { Day care sub- } \\
\text { sidies for } \\
\text { mothers only }\end{array}$ & $\begin{array}{l}\text { Day care } \\
\text { subsidies for } \\
\text { mothers and } \\
\text { for fathers } \\
\text { (with condi- } \\
\text { tions) }\end{array}$ & $\begin{array}{l}\text { Equal day } \\
\text { care subsidies }\end{array}$ & $\begin{array}{l}\text { No day } \\
\text { care subsi- } \\
\text { dies }\end{array}$ \\
\hline $\begin{array}{l}\text { All collective } \\
\text { agreements } \\
\text { (N=56) }\end{array}$ & $4 \%$ & $30 \%$ & $2 \%$ & $64 \%$ \\
\hline $\begin{array}{l}\text { Collective } \\
\text { agreements in } \\
\text { the public sec- } \\
\text { tor (N=18) }\end{array}$ & $5.5 \% *$ & $89 \% * *$ & $5.5 \% * * *$ & 0 \\
\hline $\begin{array}{l}\text { Collective } \\
\text { agreements in } \\
\text { the private sec- } \\
\text { tor (N=38) }\end{array}$ & $2.5 \%$ & $2.5 \%$ & 0 & $95 \%$ \\
\hline Teva & Yes & & & \\
\hline El-Al & & & & No \\
\hline
\end{tabular}

*Although the nurses' collective agreement provides the right to mothers only, the law and the takshir extend the right towards "family rights".

**Although these collective agreements provide a right for mother only (and for father with conditions) the law and the takshir extends the rights towards "family rights".

*** The collective agreement with regard to academic staff provides 'parents rights' and not 'mothers' rights'. 